\title{
ON SOME SELECTED ASPECTS OF TEACHING AND TESTING ENGLISH GRAMMAR IN SLOVAK UPPER-SECONDARY EDUCATION
}

\author{
Martina Šipošová ${ }^{1}$
}

\begin{abstract}
The complexity of English grammar, which represents one of the most intricate language issues practised in the EFL classroom (not only) in Slovak educational context, has been intensively researched for decades. Teaching and testing grammar as two sides of the same coin represent a complex of aspects which EFL teachers still cast doubt on. This article deals with the concept of teaching and testing upper-secondary students' knowledge of grammar which is put in the framework of methodology of grammar teaching and testing. The author sheds light on upper-secondary students' knowledge of grammar measured through selected types of grammar tasks administered in to a group of 770 Slovak grammar school students. The research results are based on a quantitative research paradigm, and the samples were statistically tested by the non-parametric Friedman test with post-hoc pairwise comparisons, and supplemented by the repeated-measures ANOVA test. Since grammar school Slovak teenage learners of English are obliged to pass a school-leaving exam including tasks examining their knowledge of grammar, the author points out basic incongruence concerning students' actual performance in selected grammar test tasks.
\end{abstract}

UDC Classification: 373, DOI: 10.12955/cbup.v7.1432

Keywords: English, grammar, teaching, testing, decontextualized sentences, upper-secondary education

\section{Introduction}

No other language issue has so preoccupied language-teaching scholars, educators, educational researchers, linguists as well as language teachers as the concept of grammar - its role in the language classroom; approaches to grammar teaching and learning in the language classroom; teacher cognition in grammar; measuring and testing students' knowledge of grammar, etc. (Batstone, 1994; Borg, 1998a, b,; Borg 1999a, b, c, d; Borg 2003; Brown, 2001; Cullen, 2001; Ellis, 2006; Johnson, 1996; Lojová, 2004; Lojová, 2014; Lojová, 2015; Lojová, 2016; Newby, 2003; Newby, 2006; Rafajlovičová, 2000; Rafajlovičová, 2003; Rafajlovičová, 2013; Scrivener, 2005; Spada, 2007; Thornbury, 1999; Ur, 2012). Different views of theorists and practitioners take into consideration a representation of different teaching methods and approaches viewing the status of grammar within each of them. With regard to this, diversity of notions include the basic distinction between inductive versus deductive approaches to grammar teaching, the functional-notional approach to grammar teaching, the application of the Presentation-Practice-Production Model (PPP) of grammar teaching, teaching grammar in situational contexts or following task-based language teaching (TBLT). Furthermore, the Johnson Model of teaching grammar as a skill distinguishing between declarative knowledge (i.e., knowledge about a linguistic form) and procedural knowledge (i.e., being able to utilise a particular structure/form to understand or produce language instantly, without necessarily being able to explain the rule behind it) has been the focus of substantial research. The Pendulum Metaphor (applied to the history of language teaching) can also be applied to grammar teaching. We have seen a pendulum swing in grammar teaching setting off from a structural view of language, i.e. language is a linguistic system made up of structural rules and vocabulary (the well-established Grammar-Translation Method and its many variants, e.g. Audio-lingual Method) through the functional view of language where language is perceived as a linguistic system as well as a means for accomplishing goals, to an interactional view of language where language is considered a communicative tool to maintain social relations (e.g. Communicative language teaching, particularly the Deep-end Approach to CLT which is based on the belief that grammar is acquired subconsciously in communicative situations, so it is considered pointless to teach grammar explicitly).

Owing to the dissatisfaction with the communicative methods which are purely meaning-based, Long (1999) came up with two approaches which are focus-on-forms, and focus-on-form, covered by the umbrella term form-focused instruction. In brief, focus-on-forms views language divided into isolated linguistic parts and taught in an ordered manner through explicit explanation of grammar rules and immediate error correction. On the other hand, focus-on-form is a type of grammar teaching in which an instructional activity is intended to make language learners pay attention to linguistic forms during meaningful communication with the emphasis placed on meaningful context. It is also important to note that Spada (2007:275) argues that "the most pervasive misconception within CLT is that it is an approach to L2 instruction that focuses on meaning to the exclusion of any attention to language form." Thereupon

\footnotetext{
${ }^{1}$ Faculty of Education, Comenius University in Bratislava, siposova@uniba.sk
} 
perpetual dichotomies that arise whenever focusing on grammar teaching, which are basically form vs. function, form vs. meaning, accuracy vs. fluency, form-based instruction vs. meaning-based instruction, intensive vs. extensive grammar instruction or simply zero grammar approach have generally been viewed throughout the history of ELT. In other words - simplified, according to Newby (2003), the categorisation has been resolved by three general ways of approaching grammar: traditional grammar teaching (e.g., Grammar-translation method and its variants), Communicative language teaching (CLT) and post-communicative approaches (e.g., Task based language teaching or Content based instruction).

Recent years have seen a growing trend of reappraising the role of grammar in English language teaching, which goes hand in hand with the denial of various alternative methods, and favours the search for alternatives to a method, emphasizing individual differences among particular groups of EFL learners. Many experts in the field (Allwright, 1991; Kumaravadivelu, 1994, 2001, 2003, 2006, 2008, 2012; Nunan, 1991; Wallace, 1998) claim that the time of packaged solutions of methods for language teaching is over. Likewise, Ellis (2006: 103) claims he does not believe (and does not think the research demonstrates) "there is just one preferred approach to teaching grammar. The acquisition of the grammatical system of L2 is a complex process and almost certainly can be assisted best by a variety of approaches." Therefore, language teachers need to try out a variety of approaches to grammar instruction in their classrooms taking into consideration the linguistic and psychological aspects of ELT, learners' variables as well as the socio-cultural and educational conditions influencing language learning.

\section{The status of grammar teaching in Slovak upper-secondary education}

According to Larsen-Freeman (2009), the pedagogic approach to the teaching of grammar in different parts of the world varies, and is influenced not only by grammatical complexness, but also by particular pedagogic/didactic traditions. For example, Sampson (1984) points out that both the teacher and the texts are considered essential models for learning in the Chinese educational system. Also, in a survey of teachers in Colombia, Schulz (2001) found that Colombian students and teachers had stronger beliefs in the effectiveness of explicit grammar teaching and error correction than did their American counterparts. Obviously, it is conventional to hear of teachers who declare they are not in favour of explicit grammar instruction, but, on the other hand, they incorporate it in their lessons since students expect and demand it in order to succeed in exams.

Drawing on the long-lasting tradition of English grammar teaching in Slovak educational context, it has to be emphasized that Slovak teachers of English rely on focus-forms approach, explicit grammar instruction followed by intensive controlled grammar practice (accuracy-oriented). Although current trends are aimed at increasing communicative (fluency-oriented) aspects of grammar within the syllabus, the reality shows that both teachers and upper-secondary students are in favour of accuracyoriented activities aimed at practising particular grammar structures. One of the reasons can be found in the aforementioned tradition, i.e. although the communicative approach to language teaching has been immensely accepted in ESL (English as a second language) classes, its application to our socio-cultural and educational context has not been thoroughly implemented yet. The other reasons lie in the Slovak curriculum requirements since all upper-secondary students have to take a final school-leaving exam (Maturita exam), which includes English-in-use test measuring the grammatical competence of students. Thus, the majority of students mistakenly think that in order to "know a language", a person should be able to produce grammatically acceptable sentences in the target language, together with an ability to use grammatical structures correctly. With regard to this, Lojová - Kostelníková (2014:26) claim "secondary school graduates achieve a relatively high level of knowledge about the target language, but their ability to use the knowledge in communication is very often inadequate." This opinion is supported by a number of research studies carried out in the Slovak educational context (Hlava, 2012; Lojová, 2004; 2015; Rafajlovičová, 2000). As Lojová - Kostelníková (2014) state, based on the questionnaire given to 1,056 upper-secondary students and 71 teachers in the year 2000, the research findings showed most of the lesson time was devoted to theoretical explanation and focused on the prescribed grammar structure exercises, the responses of the students also reached extreme numerical values in favour of traditional methods although teachers claimed to apply various communicative activities, neither the teachers nor the students demanded a reduction of declarative knowledge. One common feature dominated, all respondents agreed that the greatest difficulty for upper-secondary learners was to comprehend structural-functional characteristics of similar structures, i.e. to understand differences in the usage of similar structures and to use them correctly in real life communication. Similarly, in the 
research study carried out by Hlava (2012) in the group of 594 grammar school students and 55 teachers, the research findings showed no significant differences in students' opinions in favour of better focus on developing procedural knowledge. In particular, the students again considered the development of declarative knowledge as a dominant part of their English lessons and demanded it themselves. The students did not want to lessen the amount of declarative knowledge they were supposed to learn, and traditional teaching methods were still dominant during the lessons while communicative methods for practising the language were marginal. Furthermore, the lack of the sufficient amount of interesting and natural communicative activities for grammatical rule automization (i.e., automization of lower subskills as components of higher-level skills that can be enhanced particularly through repetition and intensive practice) was expressed from the students' point of view. Concerning teachers' opinions, the results seemed to be very similar to Lojová's research. Thus, teachers considered the use of communicative methods more dominant, although they admitted traditional teaching methods were still present in their classrooms, teachers conceded there was not enough time and space for sufficient grammatical rule automization. Slight differences between Lojová's and Hlava's research occurred in the attitude to the relevancy of the content of grammatical rule memorization with a positive shift in teachers' opinions who expressed they were aware of the irrelevancy of grammatical rule memorization to the detriment of developing the knowledge of students. In another research study, which was an experimental one, conducted in a group of 87 upper-secondary students and 9 teachers, Hlava (2015) found out that grammar teaching based on developing declarative knowledge of students to the detriment of procedural knowledge had a significant impact on the length of students' oral production. Thus, in the control group it was shown that students' speech was considerably shorter than in the experimental group. All things considered, currently the process of grammar teaching in Slovak upper-secondary education still reflects traditional approaches based on the application of grammatical rules in decontextualized sentences which leads to unsatisfactory speech production and grammar usage in real-life communication.

\section{Testing grammar viewed through Slovak educational context}

Educational researchers (Bachman, 1982; Purpura, 2004; Rafajlovičová, 2013, 2003) claim that teaching and testing grammar are closely interrelated. Therefore, it is obvious that the development of different approaches to grammar teaching had impact on the history of grammar testing. There has also been a shift from an analytical to an integrative approach utilised in language teaching and language testing, which has been viewed as a grammar-translation, structural, and communicative approach. Undoubtedly, with regard to grammar testing, it has always been considered as an important area for testing learners' language proficiency and it still takes up a principal position in a large number of school examinations, achievement as well as commercially available proficiency tests. According to Purpura (2004:3-4), "language teachers have always acknowledged the inextricable link between teaching and testing, and accordingly have always assessed their students' knowledge of grammar. In other words, the assessment of grammatical ability is nothing new. What has changed over time is what teachers have chosen to assess under the title of 'grammar' and the ways in which these assessments have been carried out. For example, at one point in time, knowledge of grammar was assessed through the ability to recite rules; at another, through the ability to extrapolate a rule from samples; and at yet, another, knowledge of grammar was tested through the ability to provide an accurate translation. Currently, knowledge of grammar might be inferred from the ability to select a grammatically correct answer from several options on a multiple-choice test, to supply a grammatically accurate word or phrase in a paragraph or dialogue; to construct grammatically appropriate sentences, or to provide judgements regarding the grammaticality of an utterance." In accordance with Purpura, Larsen-Freeman (2009:533) points out "in the traditional approach to assessing grammar, grammatical knowledge is defined in terms of accurate production and comprehension, and then assessed through the four skills. Testing is typically done by means of decontextualized, discrete-point items such as sentence unscrambling, fill-in-the-blanks, error correction, sentence completion, sentence combining, picture description, elicited imitation, judging grammatical correctness, and modified cloze passages. Such formats test grammar knowledge, but they do not assess whether test takers can use grammar correctly in real-life speaking or writing."

With regard to the Slovak educational context, the ways of testing grammar have been rather limited over the decades. Although the importance of explicit grammar testing has been much decreased in ESL educational context over the past decade(s), in Slovakia it is a common practice to test students' knowledge of grammar through decontextualized, isolated sentences and discrete-point items. 
Moreover, grammar still represents a significant criterion in the analysis of students' written and spoken language performance.

Obviously, the potency of discrete-point items is that they support high validity as well as reliability. On the other hand, their weakness is highlighted by the fact that language does not function in the way of isolated components because all four language skills are interrelated, and they cannot be separated and then tested in isolation. Therefore, when utilising isolated test formats there is a danger of testing an ability to do a particular type of test task (i.e., randomly use memorized grammar rules) rather than an ability to use the language communicatively. Contrary to the assessment of a learner's use of grammatical items extracted from the context (e.g., discrete-point items, multiple-choice tasks, etc.), an alternative approach for the assessment of grammar with the conception of contextualized items in a grammar test has been introduced. The contextualized grammar test and sentence construction are fundamentally tests of production and require the learners to organise their information first and then recall the memorized rules and patterns. As Bachman (1982) suggests, a modified cloze passage, using reasonable deletions of specified items (as opposed to random deletions, i.e. deleting every -nth word), is capable of measuring both syntactic and discourse level relationships within a text. Although there have been strong efforts in favour of testing grammar through integrative tests, or as Rafajlovičová (2013:97) points out "through some medium", "the extent to which grammar is tested through the receptive skills is rather limited." Having taken Slovak educational context into consideration, grammar testing still mirrors the best practice of the 1960s. With regard to this, Rafajlovičová (2013:98) emphasizes that fact "any move away from the objective decontextualized and decomposable approach to grammar testing raises certain difficulties. 'Communicative' testing (as indeed teaching) places greater demands on teachers and challenges their competence in English. More open-ended writing tasks, through which grammar may be tested, require a new set of skills for test design, format, and item writing, with implications for more explicit marking schemes, appropriate design and application of different rating scales. The teachers prefer using well tried methods to avoid uncertainties about how to test grammar communicatively. It can be the result of constraints imposed by a syllabus, too." Therefore

Slovak teachers of English still prefer using well tried methods and ways of testing grammar in order to avoid ambiguities in communicative grammar testing.

\section{The research objective}

As aforementioned, Slovak upper-secondary learners are exposed to explicit grammar instruction followed by intensive controlled decontextualized grammar practice in the EFL classrooms. Although they possess a relatively high level of declarative grammar knowledge, their performance in contextualized tasks is poor, evoking that their language ability is void of communicative purpose. Thus, the aim of this research study was to measure and compare students' knowledge of English grammar in three sets of selected grammar test tasks.

\section{Participants and Data Collection}

This research study was carried out in Slovak upper-secondary education, particularly, grammar schools from September to December 2018. Seven hundred and seventy upper-secondary students (aged 17 to 18) were administered a criterion-referenced achievement test.

This is a test designed to measure the degree of proficiency attained on a given set of objectives (one of its examples is a teacher-made test which helps the teacher to monitor student progress as well as diagnose strengths and weaknesses). According to Purpura (2004), individual test-tasks characteristics significantly impact performance. Therefore, the content, the length, the task types and the rating scales were specifically tailored to the group of participants and the purpose of the study. In the light of Purpura's work (2004), a grammar test should comprise more than one task type if it is to yield a holistic, multi-layered perspective of the learners' language behaviour. They distinguish and group grammar-test tasks into three groups: selected-response tasks (e.g., multiple-choice, matching activities, discrimination activities, noticing activities, grammatically judgement activities), limited production tasks (e.g., gap-filling activities, cloze activities, etc.), and extended production tasks (summaries, essays, stories, reports, etc.).

Our test was designed at B1 proficiency language level according to CEFR (Common European Framework of Reference), consisting of 10 tasks aimed at testing particular grammar structures, following Purpura's combination of selected-response tasks and limited production tasks. Prior to 
testing a pilot test was administered in order to confirm timing and avoid possible ambiguities. The length of the test was set to 60 minutes.

\section{Research results}

Prior to statistical processing, the test tasks were divided into three sets of particular tasks. Set A tasks included tasks aimed at testing students' declarative knowledge of grammatical rules based on selectedresponse tasks (mainly noticing tasks and grammatically judgement activities). Set B tasks included decontextualized selected-response tasks in the form of discrete-item tasks, i.e. multiple-choice and verb form completion. Set $C$ tasks were contextualized limited-production tasks - modified cloze activity and gap-filling activity aimed at testing variety of tenses on the basis of verb form completion in context. Having checked students' answers, the three sets of tasks (A, B and C) were statistically compared. All statistical teste were done using the PAST statistical package (https://folk.uio.no/ohammer/past/).

Comparison of three sets of test task (A, B and C)

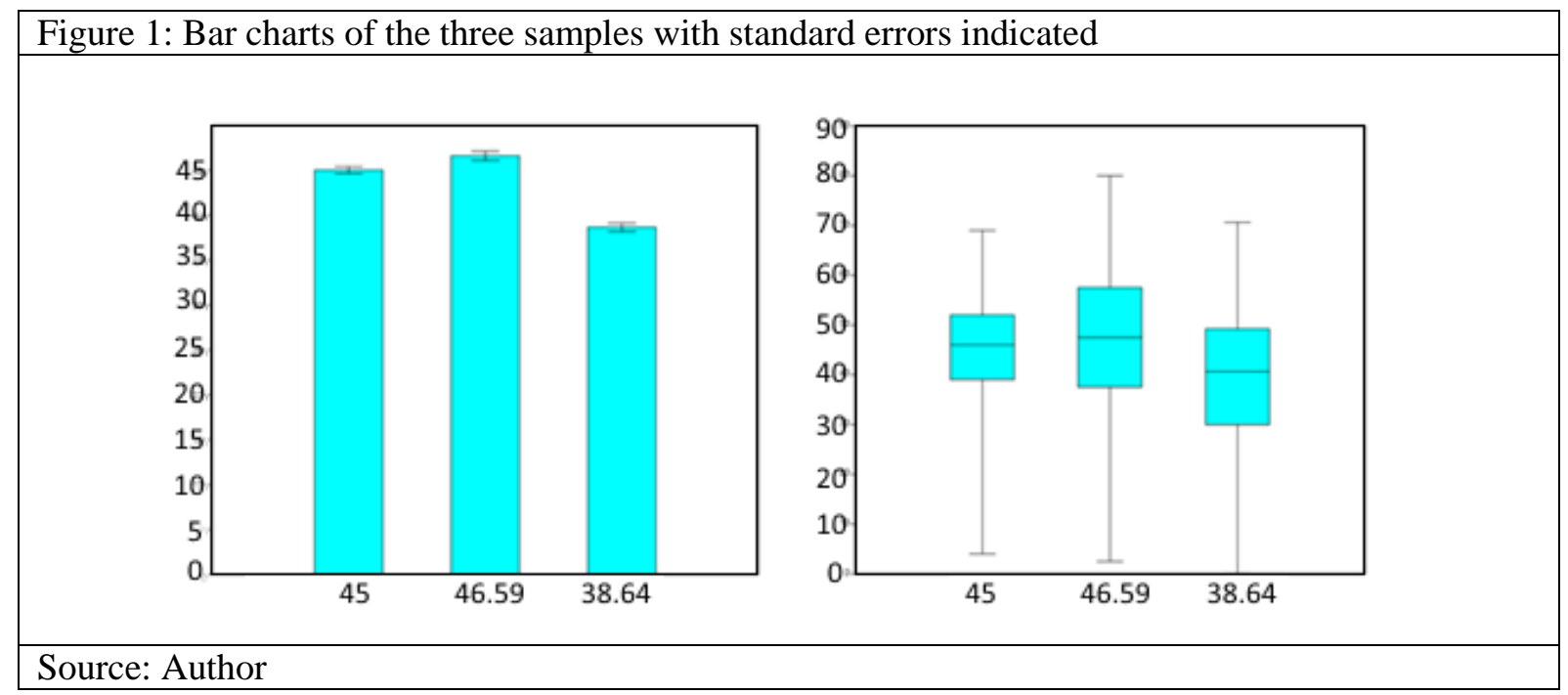

None of the samples had a normal (Gaussian) distribution, even after log-transformation. The samples therefore remained in their original non-transformed way.

The three groups were compared statistically by means of the non-parametric Friedman test (which is used for testing the differences among repeated measures), and we also used tentatively the repeatedmeasures ANOVA (despite the non-Gaussian distribution).

\begin{tabular}{|ccccccccc|}
\hline \multicolumn{10}{|l|}{ Table 1: Basic descriptive statistics of A, B, C samples (sets of test tasks) } \\
\hline & \multicolumn{10}{c|}{ Test task } & $\mathrm{n}$ & $\Sigma$ & $\mathrm{M}$ & $\mathrm{SD}$ & $\mathrm{s}$ & $\mathrm{s}$ & Median & $\begin{array}{c}\text { Geom. } \\
\text { mean }\end{array}$ \\
\hline $\mathrm{A}$ & 774 & 34835 & 45.00646 & 10.70255 & 114.5446 & 0.3846952 & 46 & 43.46317 \\
$\mathrm{~B}$ & 774 & 36067.5 & 46.59884 & 14.08727 & 198.4511 & 0.5063563 & 47.5 & 43.8884 \\
$\mathrm{C}$ & 774 & 29912.92 & 38.64718 & 13.05217 & 170.3591 & 0.4691506 & 40.66 & 0 \\
\hline \multicolumn{1}{l}{ Source: Author }
\end{tabular}

Friedman test for equal medians

This is a non-parametric test for the comparison of 3 or more paired groups. The results of the comparison of the samples $\mathrm{A}, \mathrm{B}$, and $\mathrm{C}$ is that the differences in the students' performance due to the task type were statistically significant: $\chi 2(2)=269.77, \mathrm{p}<0.001$. The post-hoc Wilcoxon pair-wise comparison test with Bonferroni-corrected $\mathrm{p}$ values has shown that there are statistically significant differences among all three groups, namely between task type A and B $(p=0.004)$, A and $C(p<0.001)$, and $\mathrm{B}$ and $\mathrm{C}(\mathrm{p}<0.001)$.

The result shows that there are statistically significant differences among the tested samples. The $p$ value of the Levene's test for homogeneity of variance was smaller than 0.05 which means that the tested samples have different variance. 


\begin{tabular}{|c|c|c|c|c|c|}
\hline & SS & $\mathrm{df}$ & MS & $\mathrm{F}$ & $\mathrm{p}$ (same) \\
\hline Between groups & 27400.9 & 2 & 13700.4 & 183.7 & $\mathrm{p}<0.001$ \\
\hline Within groups & 373633 & 2319 & 161.118 & & \\
\hline Error & 115311 & 1546 & 74.5864 & & \\
\hline Between subjects & 258323 & 773 & 334.182 & & \\
\hline Total & 401034 & 2321 & & & \\
\hline
\end{tabular}

Tukeys post-hoc pair-wise comparison tests have shown that there are statistically significant differences among all three groups $\mathrm{A}, \mathrm{B}$, and $\mathrm{C}: \mathrm{p}<0.001$.

\section{Discussion}

Based on the above results we can conclude that the tested students are most proficient in set B tasks decontextualized selected-response tasks in the form of discrete-item tasks, i.e. multiple-choice and verb form completion, less proficient in set A tasks - selected-response tasks, i.e. noticing tasks and grammatically judgement activities, and the least proficient in set $C$ tasks - contextualized limitedproduction tasks, i.e. modified cloze activity and gap-filling activity aimed at testing a variety of tenses on the basis of verb form completion in context.

In accordance with Rafajlovičová's (2000) research which showed that students did significantly better in decontextualized tasks and focused grammar structure tasks than in tasks embedded in context, we have to assert that there has not been any significant change in students' grammar performance over almost two decades (from 2000 to 2018).

Although it has been suggested multiple-choice tasks are inauthentic language-use tasks and may not tap into the learners' skill in the same way as, for example, extended production tasks (see Purpura's distinction), it has been put forward that valid inferences about the learners' ability can be made. Regarding set B tasks, which measured the learners' recognition or recall of the target grammatical form and meaning (receptive knowledge), it has been shown that learners did much better on the receptive knowledge than in limited production contextualized tasks which were intended to measure the learners' (rather limited) productive knowledge of the target language structures (i.e., tenses in context and modified cloze activity).

These research findings shed light on the interrelation between teaching and testing English grammar in the Slovak educational context, which is still characterized as the focus-forms approach, explicit grammar instruction followed by intensive controlled grammar practice, therefore resulting in better learners' performance concerning the receptive knowledge of grammar.

In spite of the fact that these findings demonstrate no significant change in the traditional paradigm of grammar teaching, practising as well as preparing upper-secondary students for grammar tests, slight modifications have been identified based on the set A test tasks results which were aimed at measuring students' knowledge of memorized grammatical rules. Therefore, it seems rote learning of grammatical rules has given way, at least, to the application of rules in sentences.

\section{Conclusion}

Undoubtedly, the pedagogic approach to the teaching of English grammar in various parts of the world also depends on the pedagogic traditions of the particular country. The situation in the Slovak educational context demonstrates long-lasting traditions rooted in traditional teaching approach(es) consisting of focus-on-forms, explicit grammar instruction followed by intensive drills and controlled grammar practice which learners, unsurprisingly, do not reject, on the contrary, they are in favour of them. Therefore, many language learners in Slovak schools can satisfactorily complete grammar exercises when their attention is focused on the grammar, but as soon as the attention shifts to communicative interactions, at least, in the form of contextualized grammar practice, the grammar is forgotten or simply, used incorrectly. This situation has been completely verified by the presented 
research study. The researcher supposes that the group of "researched" upper-secondary learners who succeeded in set B tasks (decontextualized multiple-choice and verb form completion tasks) were only focused on particular English grammar structures without having to worry about their meaningful contextualized usage. They could do most of the items with the reference to their knowledge of language rules. Since the set B tasks test did not require any sort of contextualized language production on the side of the grammar school students, they were only concerned with a non-communicative practice.

Many grammar knowledge tests consist of isolated grammar items, decontextualized sentences, and a focus on a particular structural rule within a given statement. Such grammar items require examinees to recognize a grammatical structure in a given sentence and could be answered by attending to grammatical clues which can be extensively exercised by studying sample tests resulting in learners' getting test-wise, but not necessarily able to use language forms appropriately when producing language. Obviously, grammar knowledge has to be put into use when comprehending or producing language, therefore, teachers should test it in use. It has to be emphasized that if language testing acts as a complementary practice to language teaching, we believe that it is more beneficial to assess learners' knowledge of grammar by challenging their ability of using this knowledge in meaningful language production, not just decontextualized grammar structure recognition.

\section{Acknowledgment}

This article is an output of the project VEGA 1/0495/17 The Interrelationship between mental representations of the English language system, performance in metalinguistic tasks and production in communicative situations in English language teaching.

\section{References}

Allwright, R. L. (1991). The death of the method (Working Paper No. 10). Lancaster, England: The University of Lancaster, The Exploratory Practice Centre.

Bachman, L. (1982). Trait Structure of Cloze Test Scores. TESOL Quarterly, 16 (1), 61-70.

Batstone, R. (1994). Grammar. Oxford: Oxford University Press.

Borg, S. (2003). Teacher cognition in grammar teaching: A literature review. Language Awareness, 12 (2), 96-108.

Borg, S. (1999a). The use of grammatical terminology in the second language classroom. Applied Linguistics 20 (1), 95-126.

Borg, S. (1999b). Studying teacher cognition in second language grammar teaching. System, 27 (1), 19-31.

Borg, S. (1999c). Teachers' theories in grammar teaching. ELT Journal, 53 (3), 157-67.

Borg, S. (1999d). The use of grammatical terminology in the second language classroom: A qualitative study of teachers' practices and cognitions. Applied Linguistics, 20 (1), 95-126. Retrieved from https://doi.org/10.1093/applin/20.1.95

Borg, S. (1998a). Talking about grammar in the foreign language classroom. Language Awareness, 7 (4), 159-175.

Borg, S. (1998b). Teachers' pedagogical systems and grammar teaching: A qualitative study. TESOL Quarterly, 32 (1), 9-38. Retrieved from https://doi.org/10.2307/3587900

Brown, H.D. (2001). Teaching by Principles: An Interactive Approach to Language Pedagogy, Second Edition. N.Y.: Pearson Education.

Cullen, R. (2001). Beyond PPP: towards a learning-centered approach to teaching grammar. In Mora, H. et al. (eds), Teaching English in a Spanish setting. Valencia: Universidad de Valencia.

Ellis, R. (2006). Current Issues in the Teaching of Grammar: An SLA Perspective. TESOL Quarterly, March 2006, Vol. 40, No. 1, 83-107. Retrieved from https://doi.org/10.2307/40264512

Hlava, T. (2015). Dimenzia vyučovania gramatiky: rozvíjanie plynulosti ústneho prejavu. Bratislava: Z-F LINGUA.

Hlava, T. (2012). Efficiency of teaching English grammar in higher secondary education in Slovakia. MMK 2012, roč. 3 [elektronický zdroj] Hradec Králové : MAGNANIMITAS.

Johnson, K. (1996). Language Teaching and Skill Development. Oxford: Blackwell Publishers.

Kumaravadivelu, B. (2012). Language teacher education for a global society. Routledge: Taylor\& Francis.

Kumaravadivelu, B. (2008). Understanding Language Teaching: From Method Postmethod. Taylor \& Francis e-Library. Retrieved from https://livelongday.files.wordpress.com/2011/08/kumaraposmethod.pdf

Kumaravadivelu, B. (2006). Understanding language teaching: From method to postmethod. Mahwah, NJ: Lawrence Erlbaum Associates.

Kumaravadivelu, B. (2003). Beyond Methods: Macrostrategies for Language Teaching. New Haven, CT: Yale University Press.

Kumaravadivelu, B. (2001). Towards a postmethod pedagogy. TESOL Quarterly, 35 (4), 537-60. Retrieved from https://doi.org/10.2307/3588427

Kumaravidvelu, B. (1994). The postmethod condition: (E)merging strategies for second/foreign language teaching. TESOL Quarterly, 28 (1), 27-48. Retrieved from https://doi.org/10.2307/3587197 
Larsen-Freeman, D. (2009). Teaching and Testing Grammar. In Long, M.H. \& Catherine, J. Doughty (ed.), The Handbook of Language Teaching. (pp. 518-542), Malde, MA: Wiley Blackwell.

Lojová, G. (2016). Current situation in the research of teaching English grammar in Slovakia. XLinguae, 9 (3), 70-80.

Lojová, G. et al. (2015). Deklaratívne a procedurálne vedomosti vo výučbe anglického jazyka. Bratislava: UK v Bratislave.

Lojová, G. - Kostelníková, M. (2014). Enhancing the Effectiveness of Teaching EFL Grammar in Slovakia. Studies in Foreign Language Education, Vol. 6, Kirsch-Verlag: Nümbrecht.

Lojová, G. (2004). Teória a prax vyučovania gramatiky cudzích jazykov. Bratislava: Monitor Promotion.

Long, M. (1999). Focus on form: A design feature in language teaching methodology. In K.De Bot, R. Ginsberg, and C. Kramsh (Eds.), Foreign language research in cross-cultural perspective. (pp. 39-52), Amsterdam: John Benjamin.

Newby, D. (2006). Teaching grammar and the question of knowledge. In A.B. Fennerand and D. Newby (eds.), Coherence of Principles, Cohesion of Competences: Exploring Theories and Designing Materials for Teacher Education. Graz/Strasbourg: European Centre for Modern Languages/Council of Europe Press, 1-11. Retrieved from https://static.uni graz.at/fileadmin/gewi

Newby, D. (2003). Cognitive + Communicative Theory of Pedagogical Grammar.

Habilitationsschrift. Karl-Francens Universität Graz. Retrieved from https://static.uni-graz.at/fileadmin/gewiinstitute/Anglistik/Fachdidaktik/Downloads/angl3www_newby_pedagogical_grammar.pdf

Nunan, D. (1991). Language teaching methodology. London: Prentice-Hall Purpura, J. E. (2004). Assessing grammar. UK: Cambridge University Press.

Rafajlovičová, R. (2013). Grammar Tests as a Reliable Measure of Language Competence. Zvyšování kvality výuky a testování cizích jazykú. (pp.96-101). Univerzita Karlova v Praze, Ústav jazykové a odborné př́ípravy. Czech Republic. Retrieved from http://ujop.cuni.cz/upload/stories/vtc/konference/UJOP_2013_konference_sbornik.pdf

Rafajlovičová, R. (2003). The Status of Grammar in Language Teaching and Learning - Different Approaches to its Testing. Studia Philologica, Annus XI, FHPV PU, 126-132.

Rafajlovičová, R. (2000). Testing verb forms through discrete-point and open-ended tasks. Prešov: Prešovská univerzita. Sampson, G. (1984). Exporting language teaching methods from Canada to China. TESL Canada Journal 1 (1), 19-31. Scrivener, J. (2005). Learning Teaching. Oxford: Macmillan Education.

Schulz, R. (2001). Cultural differences in student and teacher perceptions concerning the role of grammar instruction and corrective feedback: USA and Colombia. Modern Language Journal 85 (2), 244-57.

Spada, N. (2007). Communicative Language Teaching: Current Status and Future Prospects. In Cummins, J. and Davison, C. (eds), International Handbook of English Language Teaching. Part I. (pp.271-288), N.Y.: Springer.

Thornbury, S. (1999). How to Teach Grammar. Essex: Pearson Education Limited.

Ur, P. (2012). A Course in English Language Teaching. Cambridge: CUP.

Wallace, M. (1998). Action research for language teachers. Cambridge: CUP. 